\title{
Miss Joan Scruton MBE
}

\section{Secretary General of the International Stoke Mandeville Wheelchair Sports Federation}

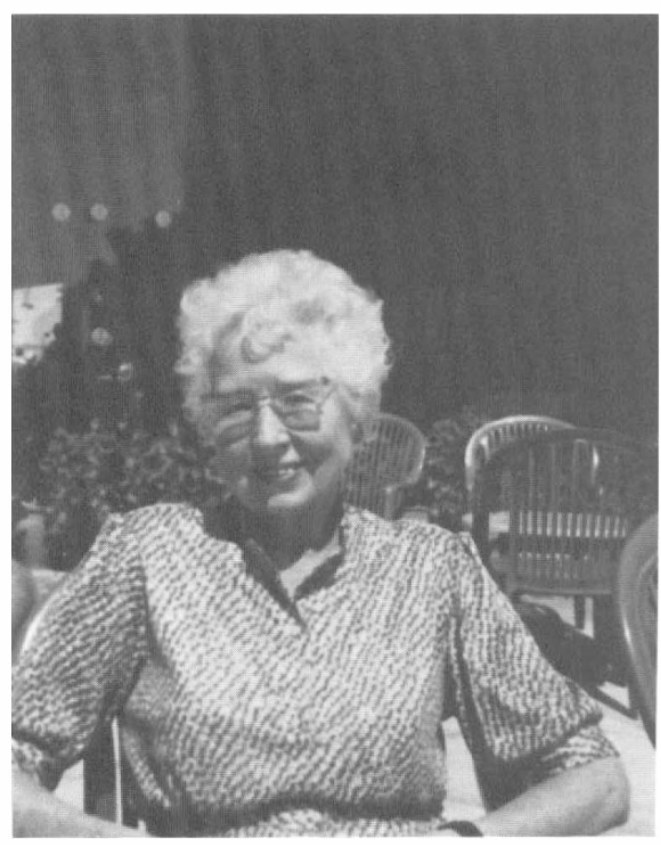

Miss Joan Scruton MBE

It has been my very good fortune to know Miss Joan Scruton personally since 1944 when she came on to the staff of the newly formed Spinal Injuries Centre in Stoke Mandeville Hospital, Aylesbury, Bucks, England, as Dr (subsequently Sir) Ludwig Guttmann's first secretary.

I have visited that centre almost every year since 1944, sometimes more than once a year. I have also had the opportunity of being involved with the sports movement for the disabled instituted by Sir Ludwig and was able to be the founder and first chairman of the Scottish Sports Association for the Disabled, being fascinated by the work of Sir Ludwig and Joan.

It is most appropriate to have a profile of this charming, extremely hard working and dedicated lady in our journal and I was very pleased to obtain the close cooperation of Joan in this respect and have also received some useful and important comments and information from Dr John M F Grant, the director of the International Stoke Mandeville Games Federation.

In May 1942, Miss Scruton, at her own request, was transferred as a civil servant to the Ministry of Pensions Hospital in Stoke Mandeville which, at that time, was admitting convoys of wounded servicemen and women injured in the War. She was put in charge of the typing pool. Then, in February 1944 Dr Ludwig Guttmann, at the request of the British government, founded the Spinal Injuries Centre in Stoke Mandeville Hospital in preparation for the Second Front. He dictated his medical reports to Miss Scruton, who became so interested in the work that she asked him if she could apply for the job of secretary. He readily supported this application to the Ministry and thus began the 36 years of close collaboration of Miss Scruton with Sir Ludwig, until he died on 18 March 1980.

From 1944 until 1968, as secretary and later administrator of the National Spinal Injuries Centre (which it was now called) and which grew to a bed capacity of 220 , she was part of the organising team for the annual National Stoke Mandeville Games, and acted in the same capacity for the International Stoke Mandeville Games which first took place in 1952 and was involved in every annual International Games thereafter until 1968. The first Paralympic Games took place in Rome in 1960 and the International Stoke Mandeville Games Committee was formed with $\mathrm{Dr}$ Guttmann as president and Miss Scruton as secretary. In 1964 the Games were held in Tokyo and in 1968 in Israel.

In 1968, Miss Scruton was seconded by the hospital authorities to the Paraplegic Sports Endowment Fund to raise funds for the building and establishment of the Stoke Mandeville sports stadium. Indeed, these funds were raised in just over a year and the building was completed in the same period. 
Joan became a higher executive officer in the civil service in the UK but when the National Spinal Injuries Centre was transferred to the National Health Service (NHS) she opted to leave the civil service and join the NHS on a comparable grade.

The Stoke Mandeville sports stadium was opened in 1969 by Her Majesty the Queen. Miss Scruton had left the NHS to become employed as the secretary general by the British Paraplegic Sports Society, which ran the stadium as a venue for national and international games and sporting activities for disabled adults and children.

Plans were being laid and funds were being sought to build an Olympic Village adjacent to the stadium, and unfortunately, Sir Ludwig died suddenly in March 1980. Joan was promoted to become director/ secretary general with the added responsibilities for the management of the stadium. The Olympic Village was opened in 1981, in time for the International Stoke Mandeville Games at which HRH Prince Charles was the guest of honour.

In March 1988, Miss Scruton retired from the British Paraplegic Sports Society but continued to work full time as secretary general of the ISMWSF on an honorary basis, until she retired from this post on 31 March 1993.

She has received several important honorary appointments, distinctions and awards both nationally and internationally. Thus, for example, she is chairman of the British Sports Association for the Disabled, was vice patron of the Stoke Paraplegic Athletics Club from 1960-1993 - secretary general of the International Stoke Mandeville Games Federation from 1975-1982, was elected secretary general of the International Sports Organisation for the Disabled and has been involved in many committees and working groups to set up and develop organisations for sports for people of all ages with varying disabilities. She remains secretary general/treasurer of the International Coordinating Committee concerning sports organisations for the disabled.

In 1975, this distinguished lady received the award of MBE from Her Majesty the Queen. In addition, she has received honours and decorations for her work for sport and games for the disabled from governments and other bodies in several countries including The Netherlands, Japan and Korea.

She has been, and indeed still is, a vital, fascinating and industrious ambassador for sports for the disabled throughout the world, and has officially visited more than 30 countries.

Joan's important contributions to the whole development of sport for disabled persons and her dedicated work for the National Spinal Injuries Centre in Stoke Mandeville Hospital has been widely acknowledged. Being the 'right hand lady' of Sir Ludwig was also recognised by appointing her an honorary member of the International Medical Society of Paraplegia. She was also honoured at the dinner held during the recent Stoke Mandeville Games.

All of us associated with IMSOP and with Paraplegia wish Joan a long, happy period of retirement.

\author{
Phillip Harris \\ Editor, Paraplegia
}

